\title{
A novel trifluoromethyl benzopyran induces G1 cell cycle arrest and apoptosis in HeLa human cervical carcinoma cells
}

\author{
XIN ZHANG $^{1,2}$, JIYOUNG HWANG ${ }^{2}$, XIAN JIA ${ }^{1}$, DONG-SOO SHIN ${ }^{3}$, SONG YOU ${ }^{1}$ and DONG-KYOO KIM ${ }^{2}$ \\ ${ }^{1}$ Shenyang Pharmaceutical University, Shenyang 110016, P.R. China; ${ }^{2}$ Department of Biomedicinal Chemistry \\ and Institute of Basic Science, Inje University, Gimhae 621-749; ${ }^{3}$ Department of Chemistry, \\ Changwon National University, Changwon, Republic of Korea
}

Received January 8, 2013; Accepted March 26, 2013

DOI: $10.3892 /$ ijo.2013.1958

\begin{abstract}
In the present study, a biologically active 4-(trifluoromethyl)phenyl piperazin moiety waslinked to a 2,2-dimethyl $-2 H$-benzopyran template to generate $(3 R, 4 S)$-2,2-dimethyl-6nitro-4-(4-(3-(trifluoromethyl)phenyl)piperazin-1-yl) chroman $-3-o l(C 110 \mathrm{~g})$, and the cellular and molecular mechanisms by which C110g exerts cytotoxic effects on the HeLa human cervical cancer cell line were further investigated. $\mathrm{C} 110 \mathrm{~g}$ suppressed the viability of HeLa cells in both concentrationand time-dependent manner $\left(\mathrm{IC}_{50}\right.$ of $\left.17 \mu \mathrm{M}\right)$ by inducing DNA damage and G1 cell cycle arrest. Characteristic changes in nuclear morphology and Annexin V/PI staining pointed to apoptosis as the mode of cell death. The levels of p53 and p21 were increased in the C110g-treated cells, with a corresponding increase in Bax/Bcl-2 protein ratio. Subsequently, C110g induced the cytoplasmic release of cytochrome $c$ from the mitochondria accompanied by a decreased mitochondrial membrane potential and activation of caspase-3 and -9. These results confirmed that the $\mathrm{C} 110 \mathrm{~g}$ transduced the apoptotic signal via the mitochondrial pathway. Caspase- 8 , typically associated with the initiation of the death receptor pathway, was activated, suggesting the extrinsic pathway might also be involved. However, C110g did not result in reactive oxygen species (ROS) generation. Taken together, these findings indicate that the DNA damage-dependent p53-regulated mitochondrial pathway as well as the extrinsic pathway play a crucial role in C110g-induced apoptosis, which provide a better understanding of the molecular mechanisms of trifluoromethyl benzopyrans in cervical cancer.
\end{abstract}

Correspondence to: Professor Dong-Kyoo Kim, Department of Biomedicinal Chemistry and Institute of Basic Science, Inje University, 607 Aubang-dong, Gimhae 621-749, Republic of Korea E-mail: chemkdg@inje.ac.kr

Professor Song You, School of Life Science and Biopharmaceutics, Shenyang Pharmaceutical University, Shenyang 110016, P.R. China E-mail: yousong206@yahoo.com.cn

Key words: trifluoromethyl benzopyran, G1 cell cycle arrest, apoptosis, DNA damage, mitochondria

\section{Introduction}

Cancer is the second leading cause of death worldwide accounting for 7.2 million deaths in 2008 (1), and the global burden of cancer continues to increase largely, with an estimation of over 13 million cancer deaths by the year 2030. Therefore, searching for novel classes of therapeutic compounds and unveiling their molecular mechanisms are desperately needed. Numerous studies have shown that cytotoxic agents and DNA damaging agents can induce cell cycle arrest and apoptotic cell death (2-4).

Damage in the DNA leads to the activation of the phosphoinositide 3-kinase-related protein sensor kinases ATM and ATR, which initiate the DNA damage response in cooperation with other effector proteins such as p53. P53 holds the cell at a checkpoint by inducing $\mathrm{p} 21$, leading to cell cycle arrest and active DNA repair systems. If the damage is irreparable, p53 triggers senescence or apoptosis (5). Apoptosis is a highly regulated mechanism leading cells to undergo programmed cell death through two main cascades: the extrinsic and the intrinsic pathways $(6,7)$. The extrinsic pathway is characterized by the activation of death receptors and the resultant activation of caspase-8; in the intrinsic pathway, cytochrome $c$ from mitochondria to cytoplasm activates caspase- 9 and thus initiate the caspase cascade leading to apoptosis (8). The link between the caspase cascade and the mitochondria is provided by the Bcl-2 family members, which guard mitochondrial integrity and control the release of mitochondrial proteins into the cytoplasm $(9,10)$.

Natural products play important roles in both drug discovery and elucidation of complex cellular mechanisms. Despite the increased need for new natural products, their isolation and structure determination still remain a highly labor-intensive process. As a result, chemists are enthusiastic to synthesize new natural product analogues or natural product-like small molecules with biological diversities. 2,2-dimethyl-2 $\mathrm{H}$-benzopyran, a structural motif found in numerous natural products, was selected as a privileged structure (11) for the construction of natural product-like libraries with a wide range of biological activities such as potassium channel activating, anticancer, antibacterial and inhibition of protein kinases (12).

It has been well established that fluorinated, in particular trifluoromethyl substituted heterocycles have gained a 
significant place in modern drug design (13) and a large body of evidence indicates that compounds containing trifluoromethyl group were more potent on cytotoxicity in various cancer cell lines $(14,15)$. In this study, biologically active 3 -(trifluoromethyl)phenyl piperazin moiety was linked to 2,2-dimethyl-2 $H$-benzopyran template to give the formation of (3R,4S)-2,2-dimethyl-6-nitro-4-(4-(3-(trifluoromethyl)phenyl) piperazin-1-yl)chroman-3-ol (C110g) (Fig. 1A). Possible pathways and related molecular mechanisms by which $\mathrm{C} 110 \mathrm{~g}$ induces cytotoxicity in human cervical cancer HeLa cells were further investigated.

\section{Materials and methods}

Materials. The propidium iodide (PI)/RNase staining buffer and Annexin-FITC kit for apoptosis were from BD Biosciences Pharmingen (San Diego, CA, USA). Dimethyl sulfoxide (DMSO), phosphate-buffered saline (PBS, pH 7.4), 2',7'-dichlorodihydrofluorescin diacetate (DCFH-DA) and $\mathrm{N}$-acetylcysteine (NAC) were purchased from Sigma-Aldrich Chemical Co. (St. Louis, MO, USA). Eagle's minimum essential medium (EMEM), fetal bovine serum (FBS), penicillin-streptomycin and trypsin-EDTA were obtained from Hyclone Laboratories, Inc. (Logan, UT, USA). Cell Counting Kit-8 (CCK-8) was purchased from Dojindo Molecular Technologies, Inc. (Osaka, Japan). MitoProbe ${ }^{\mathrm{TM}}$ JC-1 kit was obtained from Molecular Probes, Inc. (OR, USA). The primary antibodies used were polyclonal rabbit $\mathrm{Bcl}-2$, Bax, cytochrome $c$, Apaf-1, procaspase-9, $-3,-8$ and $\beta$-actin (Cell Signaling Technology, Inc., MA, USA). Polyclonal rabbit p53 and p21 antibodies were from Santa Cruz Biotechnology (Santa Cruz, CA, USA). All other chemicals were of analytical reagent grade.

Preparation of C110g. (3R,4S)-2,2-dimethyl-6-nitro-4-(4-(3(trifluoromethyl)phenyl) piperazin-1-yl)chroman-3-ol (C110g), which appears as a light-yellow solid with the melting point $76-79^{\circ} \mathrm{C}$, was synthesized from the laboratory of Dr D.S. Shin and identified according to the spectrometric data: $[a]_{D}^{20}-143.6$ (c 1.0, $\mathrm{CH}_{2} \mathrm{Cl}_{2}$ ); ${ }^{1} \mathrm{H} \mathrm{NMR}\left(400 \mathrm{MHz}, \mathrm{CDCl}_{3}\right) \delta 1.17$ (s, 3H), 1.46 (s, 3H), $2.53(\mathrm{~d}, J=2.0 \mathrm{~Hz}, 1 \mathrm{H}), 2.93-2.99(\mathrm{~m}, 4 \mathrm{H}), 3.15-3.24$ $(\mathrm{m}, 4 \mathrm{H}), 3.74(\mathrm{~d}, J=2.0 \mathrm{~Hz}, 1 \mathrm{H}), 3.80(\mathrm{dd}, J=10.0,2.0 \mathrm{~Hz}, 1 \mathrm{H})$, $6.79(\mathrm{~d}, J=9.2 \mathrm{~Hz}, 1 \mathrm{H}), 6.99-7.06(\mathrm{~m}, 3 \mathrm{H}), 7.28(\mathrm{t}, J=8.0 \mathrm{~Hz}$, $1 \mathrm{H}), 7.97(\mathrm{dd}, J=8.8,2.4 \mathrm{~Hz}, 1 \mathrm{H}), 8.41(\mathrm{~d}, J=2.0 \mathrm{~Hz}, 1 \mathrm{H})$; ${ }^{13} \mathrm{C}$ NMR $\left(100 \mathrm{MHz}, \mathrm{CDCl}_{3}\right) \delta 18.9,26.7,49.7,50.1,63.1$, 70.5, 79.9, 112.6, 113.4, 116.2, 118.4, 119.2, 121.2, 124.7, 124.8 $\left(\mathrm{d}, J_{\mathrm{CF}}=3.1 \mathrm{~Hz}\right), 129.6,136.2,164.8,167.7,172.0 ; \mathrm{MS}(\mathrm{EI})$ m/z: $451\left(\mathrm{M}^{+}, 9 \%\right), 380$ (22), 200 (100), 172 (17), 145 (8), 56 (8). Stock solution of $\mathrm{C} 110 \mathrm{~g}$ were prepared in DMSO and kept at $4^{\circ} \mathrm{C}$. Further dilutions were made immediately prior to each experiment.

Cell lines. HeLa cells obtained from American Type Culture Collection (ATCC) were cultured in EMEM medium supplemented with $10 \% \mathrm{FBS}$ at $37^{\circ} \mathrm{C}$ in an atmosphere of $5 \% \mathrm{CO}_{2}$.

Cell viability and proliferation assay. Cell viability was determined by WST-8 [2-(2-methoxy-4-nitrophenyl)-3-(4nitrophenyl)-5-(2,4-disulfophenyl)-2H-tetrazolium] colorimetric assay capable of detecting viable cells by the production of a yellow colored formazan, which is soluble in the culture medium (16). HeLa cells were seeded in 96-well plates at $5 \times 10^{3}$ cells/well and allowed to attach overnight. Media were changed and the cells were incubated with $\mathrm{C} 110 \mathrm{~g}$ at various concentrations $(2.5,5,10,20$ and $40 \mu \mathrm{M})$ or DMSO as control for 24 and $48 \mathrm{~h}$. After respective incubation period, the cells were treated with $\mathrm{CCK}-8$ reagent for $2 \mathrm{~h}$ at $37^{\circ} \mathrm{C}$. The viable cell number is directly proportional to the production of formazan which was read as absorbance values at $450 \mathrm{~nm}$ using the multimicroplate reader (Synergy HT, Biotek ${ }^{\circledR}$ ). For the cell proliferation assay, cells were seeded at $5 \times 10^{3} / \mathrm{ml}$ media in 96-well plates and treated with $17 \mu \mathrm{M}$ of $\mathrm{C} 110 \mathrm{~g}$ or vehicle alone as control for indicated time periods.

Cell morphologic changes and Hoechst staining. HeLa cells were seeded $\left(1 \times 10^{5}\right.$ cells/well) into a 24 -well plate and treated with $17 \mu \mathrm{M}$ of $\mathrm{C} 110 \mathrm{~g}$ for $0,12,24$ and $48 \mathrm{~h}$. Cells were examined and photographed by Nikon Phase Contrast-2, ELWD 0.3 inverted microscope for the examination of morphological changes. For the Hoechst 33342 nuclear staining (17), HeLa cells were seeded into a 24 -well plate containing $10-\mathrm{mm}$ diameter sterile glass cover slips. After $\mathrm{C} 110 \mathrm{~g}$ treatment, cells were fixed with fixing solution (methanol:acetic acid = 3:1) and stained by Hoechst 33342. Observations were made using a fluorescence microscope with DAPI filter.

Annexin V-FITC/PI apoptotic analysis. Cells treated with or without $\mathrm{C} 110 \mathrm{~g}$ were collected by trypsinization, washed with PBS and stained with $5 \mu \mathrm{l}$ of Annexin V-FITC and $10 \mu \mathrm{l}$ of PI $(50 \mu \mathrm{g} / \mathrm{ml})$ for $15 \mathrm{~min}$ at room temperature in the dark. Analysis was performed by FACSCalibur flow cytometer (Becton-Dickinson, San Jose, CA, USA) with 10,000 events each time. The data were analyzed by the CellQuest software (Becton-Dickinson Instruments, Franklin Lakes, NJ, USA).

Cell cycle analysis and $\left[{ }^{3} H\right]$ thymidine incorporation. The cells treated with $\mathrm{C} 110 \mathrm{~g}$ were collected by trypsinization, fixed with PBS and $70 \%$ ethanol (v/v), and stained by PI/RNase staining buffer for $15 \mathrm{~min}$ at room temperature. The percentage of cells at different phases of cell cycle was measured by a FACSCalibur flow cytometer and the data were analyzed using Modfit software (Becton-Dickinson Instruments). To further verify the effect of $\mathrm{C} 110 \mathrm{~g}$ on the cell cycle process, $\left[{ }^{3} \mathrm{H}\right] \mathrm{dTTP}$ incorporation assay was conducted as previously described (18). Briefly, after exposure to $17 \mu \mathrm{M}$ of C110g for different time periods, cells were supplied with $\left[{ }^{3} \mathrm{H}\right] \mathrm{dTTP}$ at $1 \mu \mathrm{Ci} / \mathrm{ml}(1 \mu \mathrm{Ci}=37 \mathrm{kBq})$ and incubated for another $3 \mathrm{~h}$. The incorporated $\left[{ }^{3} \mathrm{H}\right] \mathrm{dTTP}$ was extracted in cell lysis buffer and measured in a liquid scintillation analyzer (Tri-Carb 2910TR, Perkin-Elmer Inc., USA).

Determination of ROS generation and effect on cytotoxicity by ROS scavenger. The production of ROS was monitored using a fluorescence spectrometer with an oxidation-sensitive fluorescent probe 2',7'-dichlorofluorescin diacetate (DCF-DA) (19). Briefly, after C110g treatment, cells were harvested and suspended in $0.5 \mathrm{ml}$ PBS containing DCFH-DA $(10 \mu \mathrm{M})$ for $30 \mathrm{~min}$ at $37^{\circ} \mathrm{C}$ in the dark, followed by quantitative analysis in a FACScan cytometer with the Cell Quest software. To further determine the effect of ROS on cytotoxicity induced by $\mathrm{C} 110 \mathrm{~g}$, 
A

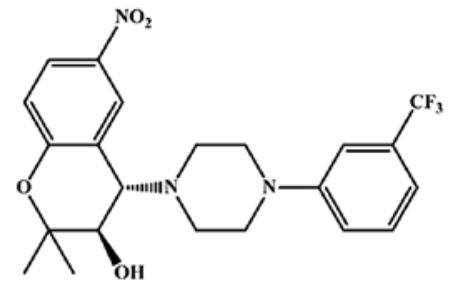

B

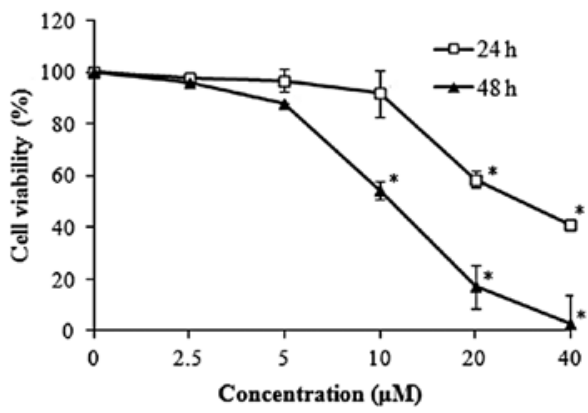

C

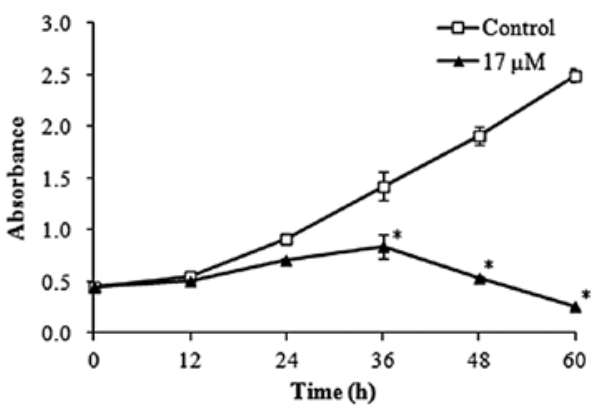

Figure 1. Viability inhibition of HeLa cells by C110g. (A) Chemical structure of $\mathrm{C} 110 \mathrm{~g}$. (B) HeLa cells were treated with different concentrations $(0-40 \mu \mathrm{M})$ of $\mathrm{C} 110 \mathrm{~g}$ for 24 and $48 \mathrm{~h}$. (C) HeLa cells were treated with $17 \mu \mathrm{M}$ of $\mathrm{C} 110 \mathrm{~g}$ for varying lengths of time $(0-60 \mathrm{~h})$, and cell viability was measured using a Cell Counting Kit- 8 . Results are the mean \pm SD, $n=3$. ${ }^{*}<<0.05$, means significantly differ from the control at the same level.

NAC, a general ROS scavenger, was added to the culture medium $1 \mathrm{~h}$ before treatment with $\mathrm{C} 110 \mathrm{~g}$. The cytotoxic effect of $\mathrm{C} 110 \mathrm{~g}$ was measured using CCK- $8 \mathrm{kit}$ in the presence or absence of ROS scavenger.

Determination of mitochondrial membrane potential $(\Delta \Psi m)$. Variations in $\Delta \Psi \mathrm{m}$ were measured using JC-1 (5,5',6,6'-tetrachloro-1,1',3,3'-tetra-ethylbenzimidazolylcarbocyanine iodide) as $\Delta \Psi \mathrm{m}$ indicator (20). Briefly, after $\mathrm{C} 110 \mathrm{~g}$ treatment, cells were harvested and suspended in $0.5 \mathrm{ml}$ PBS containing JC-1 $(2 \mu \mathrm{M})$ for $30 \mathrm{~min}$ at $37^{\circ} \mathrm{C}$ in the dark, followed by quantitative analysis in a FACScan cytometer with the CellQuest software. Carbonyl cyanide 3-chlorophenylhydrazone (CCCP), a mitochondrial membrane potential disrupter, was used as the positive control for the study of $\Delta \Psi \mathrm{m}$.

Western blot analysis. Total cell lysates and cytosolic fractions were prepared according to our previous study (21). Briefly, equal amounts of protein (20-50 $\mu \mathrm{g} /$ well) were resolved by sodium dodecyl sulfate polyacrylamide gel electrophoresis (SDS-PAGE) and transferred onto nitrocellulose membranes (Schleicher \& Schuell, USA) by western blotting. The results were quantified using ImageJ $1.43 \mathrm{C}$ ) (National Institutes of Health, Bethesda, MD, USA).
Single-cell gel electrophoresis. To examine the DNA damage in the single-cell suspensions, we performed an alkaline single-cell gel electrophoresis (comet assay). The comet assay was carried out as previously described (22). The data were analyzed using the Comet 5.5 software. Olive tail moment (OTM) approved by Olive was used to evaluate DNA damage. OTM, expressed in arbitrary units, is calculated by multiplying the percent of DNA (fluorescence) in the tail by the length of the tail in $\mu \mathrm{m}(23,24)$. The tail length is measured between the edge of the Comet head and the end of its tail. A major advantage of using the OTM as an index of DNA damage is that the amount of damaged DNA and the distance of migration of the genetic material in the tail are represented by a single number (25).

Statistical analysis. Data were collected and expressed as the mean \pm standard deviation (SD) of three independent experiments. Statistical analysis was performed by one-way analysis of variance (ANOVA) and differences from the respective controls for each experimental test condition were determined using t-tests. The criterion for significance was set at $\mathrm{P}<0.05$. The 19th version of SPSS (SPSS, Chicago, IL, USA) and Microsoft Excel 2007 (Roselle, IL, USA) were used for the statistical and graphical evaluations.

\section{Results}

C110g inhibits cell viability and proliferation in HeLa cells. The cytotoxic effect of C110g on HeLa cells was initially evaluated using WST- 8 assay. Cells were treated for 24 and $48 \mathrm{~h}$ with a range of drug doses $(2.5-40 \mu \mathrm{M})$ to determine the $\mathrm{IC}_{50}$ value of C110g. Cell viability was determined and dose response curves were plotted (Fig. 1B). Longer incubation with the drug $(48 \mathrm{~h})$, significantly reduced the $\mathrm{IC}_{50}$ value to $17 \mu \mathrm{M}$ which was used in all subsequent time course experiments. The effect of C110g on proliferation of HeLa cells is illustrated in Fig. 1C. The number of $\mathrm{C} 110 \mathrm{~g}$-treated cells gradually increased to $36 \mathrm{~h}$ and began to decrease at $48 \mathrm{~h}$, whereas the untreated cells maintained an exponential proliferation rate. A significant difference in the absorbance from the control was observed at $36 \mathrm{~h}$, showing that $\mathrm{C} 110 \mathrm{~g}$ inhibited HeLa cell proliferation after a $36-\mathrm{h}$ incubation.

Cl10g induces apoptosis in HeLa cell. Many anticancer drugs act through the induction of apoptosis (26). Microscopic examination of C110g-treated HeLa cell cultures revealed a time-dependent cell death with characteristics of apoptosis, such as cell shrinkage, membrane blebbing and fragmentation of cell into apoptotic bodies (Fig. 2A). Hoechst 33342 staining confirmed apoptotic death by the appearance of nuclear fragmentation and chromatin condensation in C110g-treated cells (Fig. 2B). To quantify the apoptosis triggered by $\mathrm{C} 110 \mathrm{~g}$, cells were stained with Annexin V-FITC/PI, and subsequently analyzed by flow cytometry. This double-staining method allows live non-apoptotic cells (Annexin $\mathrm{V}^{\text {negative }} / \mathrm{PI}^{\text {negative }}$ ) to be distinguished from early apoptotic cells (Annexin $V^{\text {positive/ }}$ $\left.\mathrm{PI}^{\text {negative }}\right)$ and late apoptotic cells (Annexin $\mathrm{V}^{\text {positive }} / \mathrm{PI}^{\text {positive }}$ ) $(27,28)$. After treatment with C110g for $0,12,24,36$ and $48 \mathrm{~h}$, the corresponding quantities of early and late apoptotic cells were 1.22 and $3.26 \%, 2.65$ and 5.29\%, 11.93 and 5.81\%, 
A

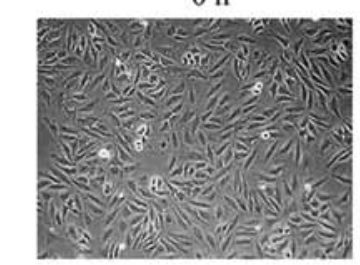

B

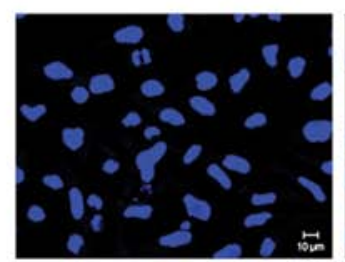

$12 \mathrm{~h}$

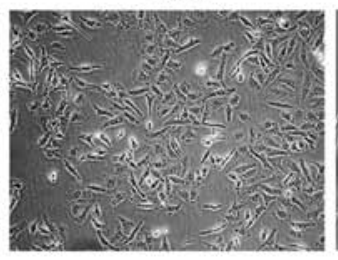

$12 \mathrm{~h}$

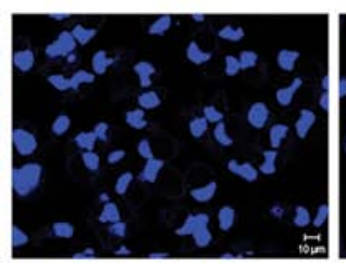

$24 \mathrm{~h}$

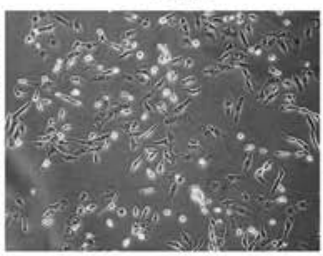

$24 \mathrm{~h}$

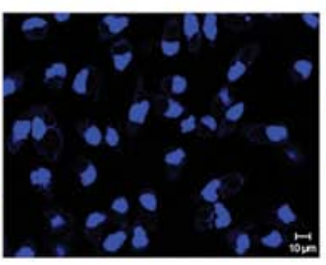

$36 \mathrm{~h}$

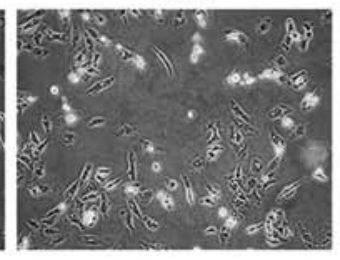

$36 \mathrm{~h}$

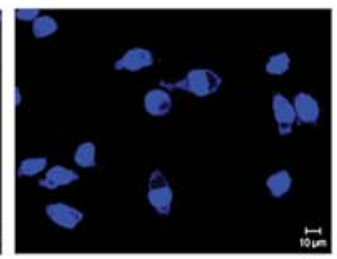

$48 \mathrm{~h}$

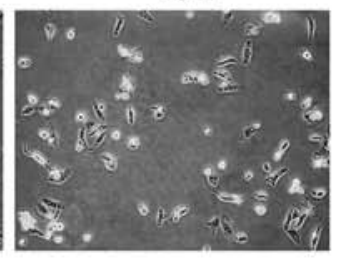

$48 \mathrm{~h}$

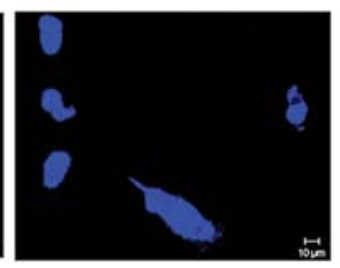

C
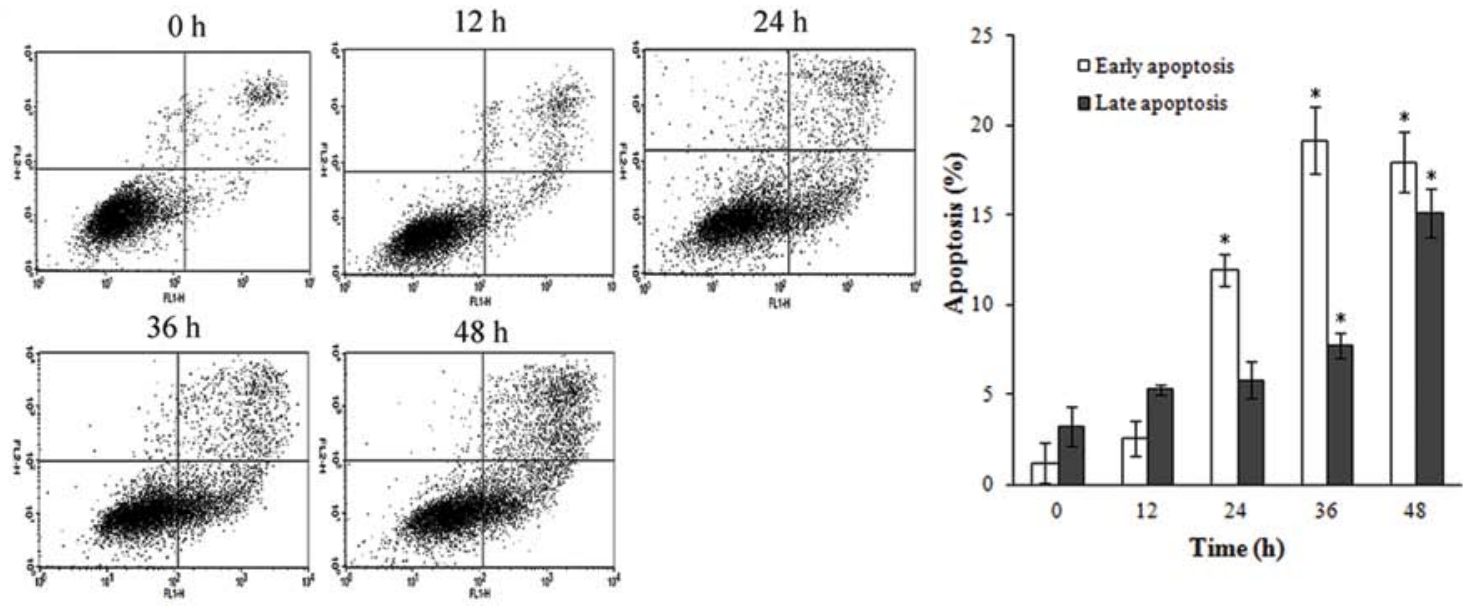

Time (h)

Figure 2. Induction of apoptosis in HeLa cells. Exponentially growing HeLa cells were treated with $\mathrm{C} 110 \mathrm{~g}$ for varying lengths of time (0-48 h) (A) Morphological changes in HeLa cells under light microscopy. Magnification, x160. (B) Nuclei changes with Hoechst 33342 staining under fluorescence microscopy. Magnification, x160. (C) Cells were harvested, stained with Annexin V-FITC/PI and analyzed for apoptosis by flow cytometry. All experiments were performed in triplicate and gave similar results. Results are the mean $\pm S D, n=3 .{ }^{*} P<0.05$, means significantly differ from the control at the same level.

19.18 and $7.7 \%$, and 17.96 and $15.11 \%$, respectively (Fig. 2C), showing that early apoptosis occurred at $24 \mathrm{~h}$ and peaked at $36 \mathrm{~h}$, while late apoptosis became evident at $36 \mathrm{~h}$ and continuously increased at tested time-points.

C110g induces p53-dependent cell cycle arrest. Flow cytometry data exhibited accumulation of cells in the G1 phase with reduction in the S-phase after 24-h treatment with C110g, whereas only modest alteration in the G2/M phases (Fig. 3A). Consequently, the G1/S ratio, which was used as an index of G1 arrest, increased significantly in a time-dependent manner in treated groups $(\mathrm{P}<0.05)$, while kept equivalent level in control group through $12-48$ h. Moreover, Fig. 3B shows a significant reduction of the $\left[{ }^{3} \mathrm{H}\right] \mathrm{dTTP}$ incorporation in $\mathrm{HeLa}$ cells during $\mathrm{S}$-phase of cell cycle, suggesting that there was an inhibitory effect of $\mathrm{C} 110 \mathrm{~g}$ on the process of DNA synthesis after $24 \mathrm{~h}$. The data reveal that the actions of C110g blocked HeLa cells in the transition from the G1 to the S-phase of cell cycle, suggesting that the observed apoptosis induced by C110g might be due to an arrest of DNA synthesis, thereby, inhibiting further progress in the cell cycle.
To further investigate the molecular mechanisms by which C110g induced G1 cell cycle arrest in HeLa cell, the expression level of G1/S-phase regulatory proteins, p53 and its effector p21 was examined using western blot analysis. As shown in Fig. 3C, p53 and p21 protein levels were markedly increased in early time-points and further decreased with time, peaking at 12 and $24 \mathrm{~h}$ respectively. These results suggest that $\mathrm{C} 110$ induces cell cycle arrest and apoptosis in a p53-dependent manner in HeLa cells.

The effects of C110g on ROS generation and $\Delta \Psi m$ level in HeLa cells. To determine the involvement of ROS in C110ginduced cytotoxicity of HeLa cells, ROS production was measured using DCF-DA. Fig. 4A shows that ROS levels were reduced in treated groups, compared with untreated control. Moreover, treatment of NAC, a general ROS scavenger, did not affect cell death induced by C110g in HeLa cells (Fig. 4B). These results indicate that $\mathrm{C} 110$-induced apoptotic cell death in HeLa cells did not require the generation of ROS.

It is known that the loss of $\Delta \Psi \mathrm{m}$ is associated with apoptotic cell death induced by various stimuli (29). In this study, 
A

$0 \mathrm{~h}$

$12 \mathrm{~h}$

$24 \mathrm{~h}$

$48 \mathrm{~h}$
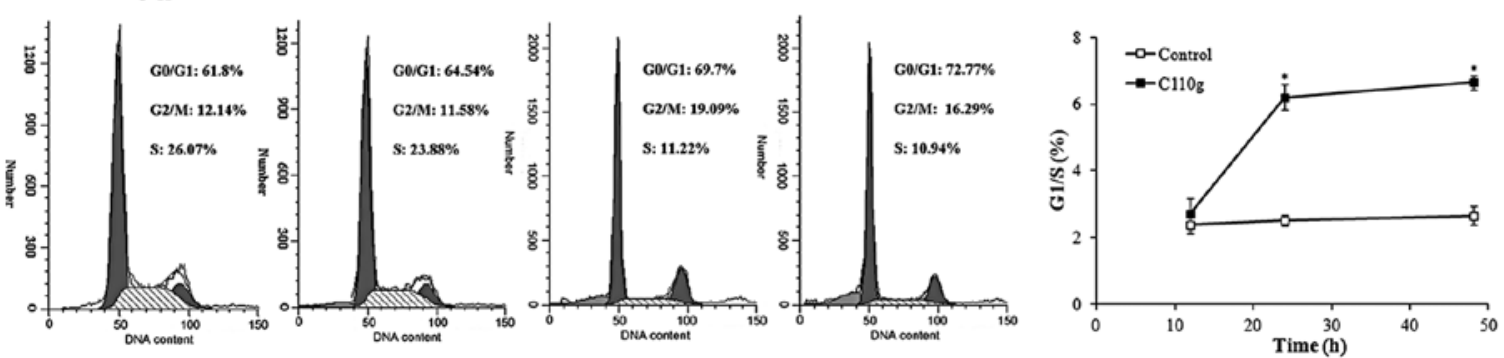

B

C

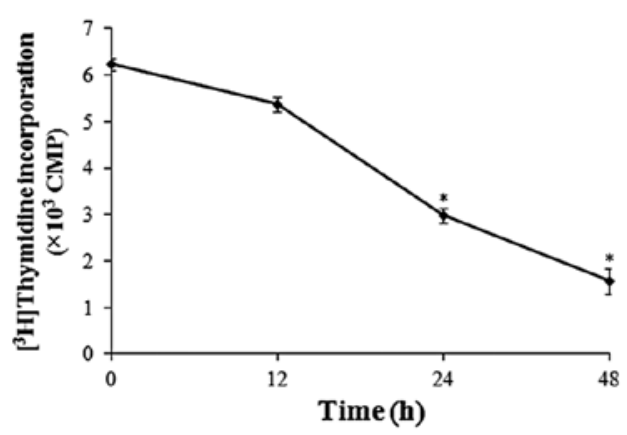

Figure 3. Effects of $\mathrm{C} 110 \mathrm{~g}$ on cell cycle distribution and expression of cell cycle regulatory proteins. (A) HeLa cells were treated with $17 \mu \mathrm{M}$ of $\mathrm{C} 110 \mathrm{~g}$ for varying lengths of time $(0-48 \mathrm{~h})$ and cell cycle distribution was monitored by flow cytometry. (B) Inhibitory effect of C110g on [ $\left.{ }^{3} \mathrm{H}\right] \mathrm{dTTP}$ incorporation of HeLa cells. (C) C110g increases the expression of p21 and 53 as determined by western blotting. Columns show the fold changes compared with equal loading control. Results are the mean $\pm \mathrm{SD}, \mathrm{n}=3$. ${ }^{*} \mathrm{P}<0.05$, means significantly differ from the control at the same level.

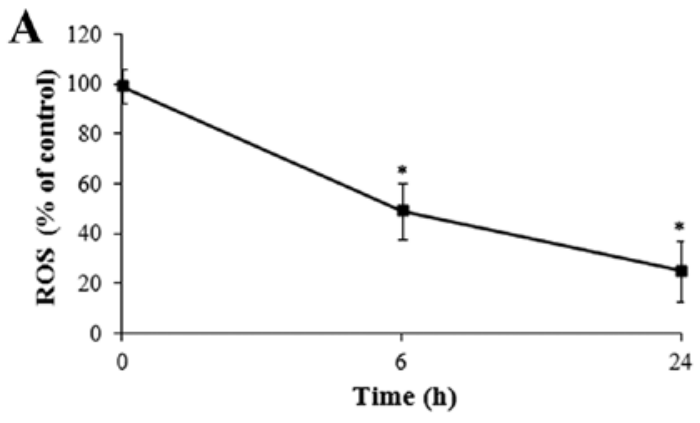

C
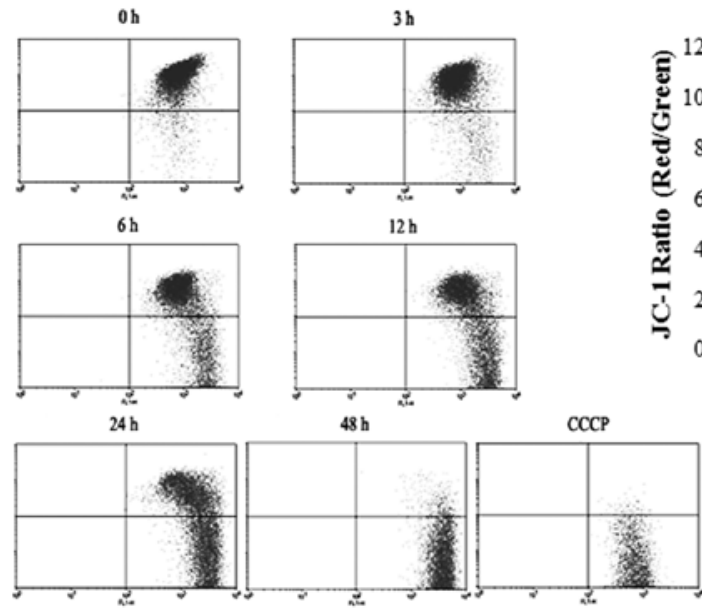
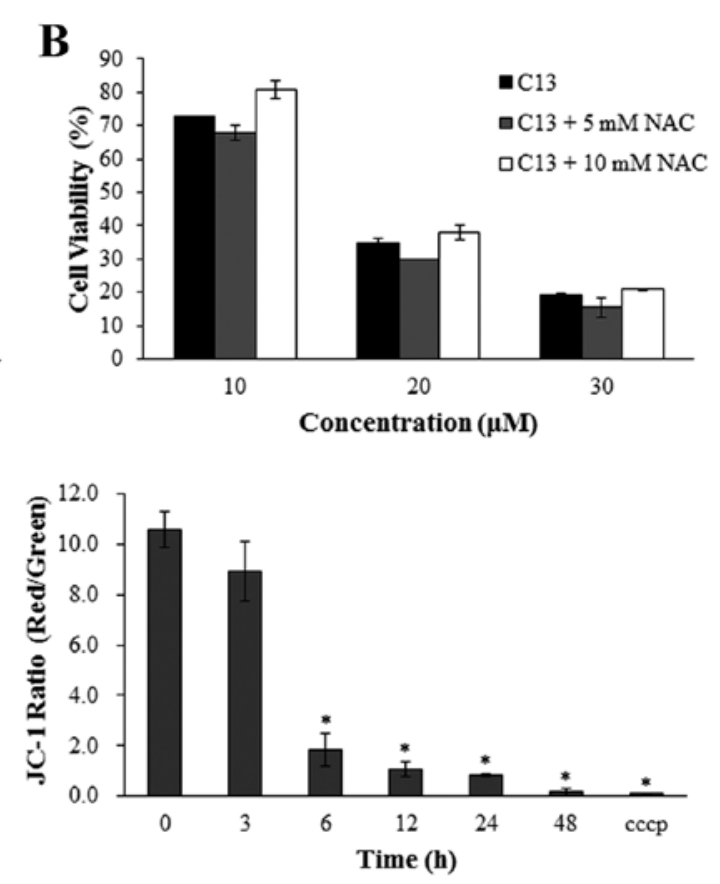

Figure 4. Effects of C110g on ROS generation and mitochondrial membrane potential $(\Delta \Psi \mathrm{m})$. (A) Cells treated with C110g were incubated with DCF-DA and the intracellular levels of ROS were determined by measuring the level of DCF fluorescence. (B) Viability inhibitory effects of NAC, a general ROS scavenger, were analyzed in $17 \mu \mathrm{M} \mathrm{C} 110 \mathrm{~g}$-treated cells using a Cell Counting Kit-8. (C) Cells were incubated with $17 \mu \mathrm{M}$ of C110g for varying lengths of time (0-48 h) and then analyzed by JC-1 derived fluorescence. Results are the mean $\pm \mathrm{SD}, \mathrm{n}=3$. "P<0.05, means significantly differ from the control at the same level. 

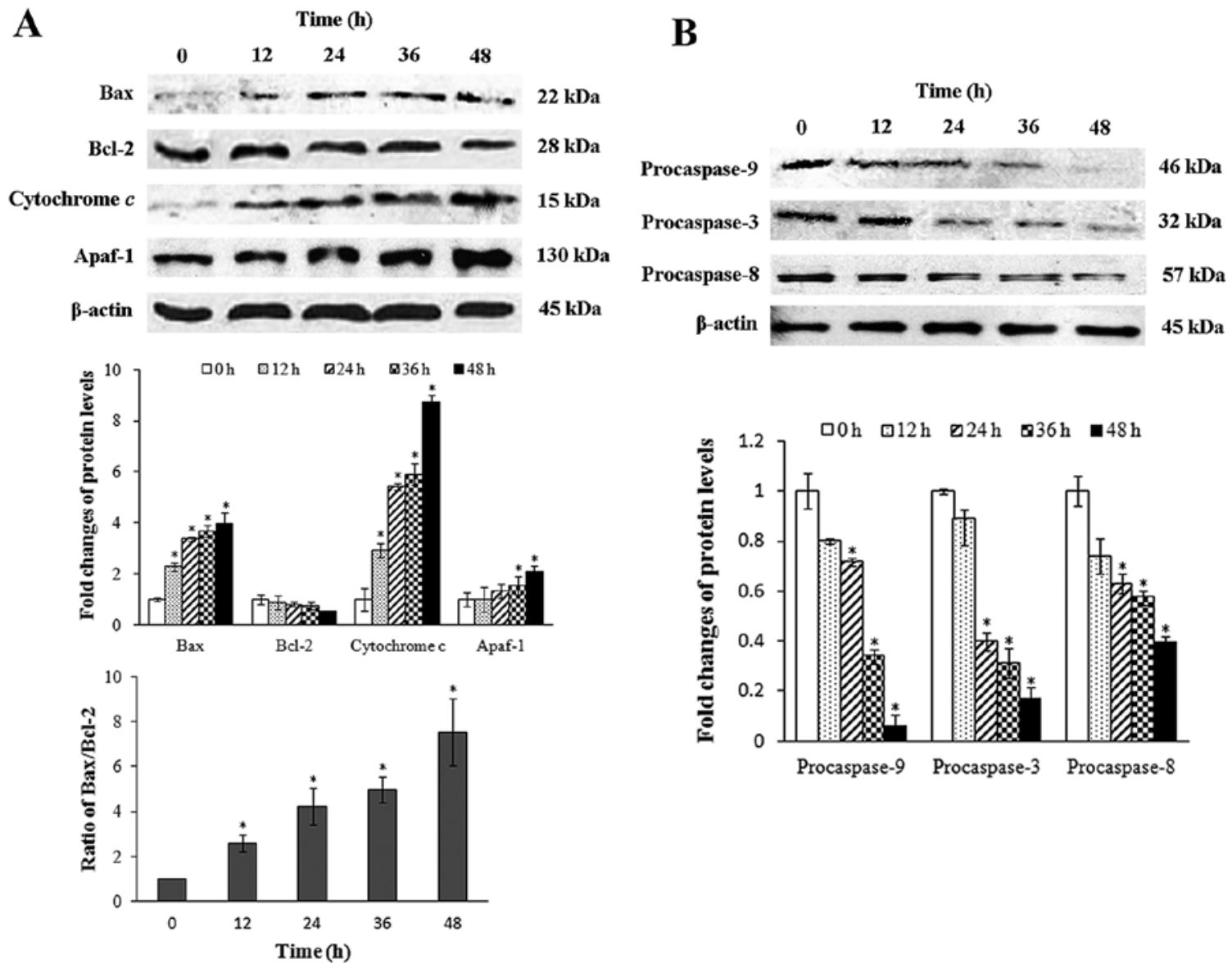

Figure 5. Involvement of protein activation in C110g-induced apoptosis. (A) C110g regulates the expression of Bax, Bcl-2, cytosol cytochrome $c$ and Apaf-1 as determined by western blotting. (B) C110g decreases the expression of procaspase- $9,-3$ and -8 as determined by western blotting. Columns show the fold changes compared with equal loading control. Results are the mean $\pm \mathrm{SD}, \mathrm{n}=3$. ${ }^{*} \mathrm{P}<0.05$, means significantly differ from the control at the same level.

JC-1, a mitochondria-specific and voltage-dependent dye, was employed to determine whether the mitochondrial metabolism played a role in the apoptosis of HeLa cell by C110g. The mitochondrial depolarization is indicated by a decrease in the red/green fluorescence intensity ratio. As shown in Fig. 4C, treatment of cells with $\mathrm{C} 110 \mathrm{~g}(17 \mu \mathrm{M})$ after $6 \mathrm{~h}$ or positive control CCCP resulted in significant depolarization of $\Delta \Psi \mathrm{m}$ as revealed by a dramatic change in fluorescence from red to green $(\mathrm{P}<0.05)$. Marked collapse of $\Delta \Psi \mathrm{m}$ demonstrate that dysfunction of mitochondria may be involved in the apoptosis induced by $\mathrm{C} 110 \mathrm{~g}$.

$C 110 g$ regulates Bax and $\mathrm{Bcl}-2$, induces cytochrome c release and causes activation of caspases. Bcl-2 family of proteins, which comprises both pro-apoptotic and anti-apoptotic members, play an important role in p53-dependent apoptosis (30). In our experiments, after treatment with $\mathrm{C} 110 \mathrm{~g}$, the proapoptotic protein Bax was pronouncedly elevated $(\mathrm{P}<0.05)$, while the anti-apoptotic member Bcl-2 was kept in equivalent level (Fig. 5A). Correspondingly, the ratio of $\mathrm{Bax} / \mathrm{Bcl}-2$, which is crucial for activation of mitochondrial apoptotic pathway, increased dramatically $(\mathrm{P}<0.05)$. Furthermore, cytochrome $c$ was released from the mitochondria to the cytosol and Apaf-1 protein expression was increased. Caspases are another important family of proteins involved in the downstream events of p53-mediated apoptosis (7). Decreases in procaspase $-3,-8$

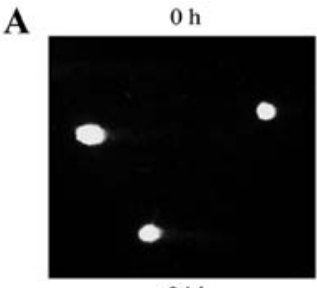

$24 \mathrm{~h}$

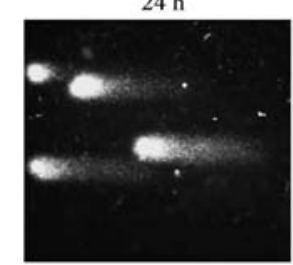

$\mathbf{B}$

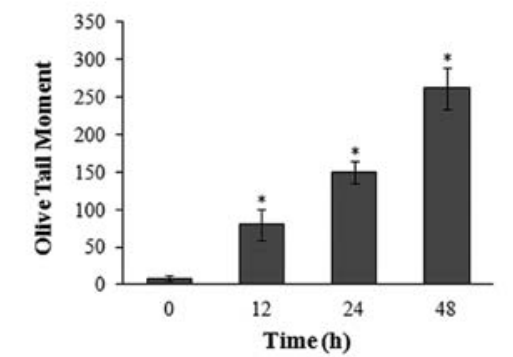

Figure 6. Induction of DNA-strand breaks in HeLa cells. (A) DNA singlestrand breaks induced by $\mathrm{C} 110 \mathrm{~g}$ in HeLa cells. (B) Olive tail moment of DNA from $17 \mu \mathrm{M}$ C110g-treated HeLa cells. Results are the mean $\pm \mathrm{SD}, \mathrm{n}=3$. ${ }^{*} \mathrm{P}<0.05$, means significantly differ from the control at the same level. 


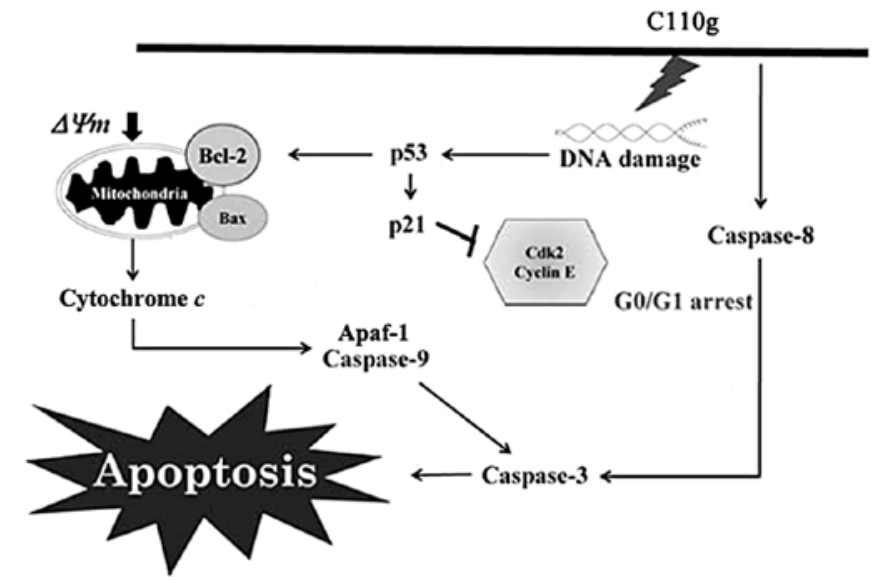

Figure 7. The proposed model of molecular signal pathways in HeLa cells after exposure to $\mathrm{C} 110 \mathrm{~g}$.

and -9 expression levels were observed $(\mathrm{P}<0.05)$, demonstrating the activation of caspase cascade (Fig. 5B).

C110g induces DNA damage. Damage in DNA initiates the DNA damage response, which cooperates with the effector proteins such as p53 inducing cell cycle arrest and DNA repair or apoptosis (31). To determine directly if C110g induces DNA damage, we performed an alkaline comet assay, a sensitive method that detects DNA single- and double-strand breaks, alkali-labile sites, and incomplete excision repair sites at the single-cell level based on the increased tail of DNA migration (32). As Fig. 6 shows, the DNA from C110g treated cells exhibited typical formation of comet, while control cells showed a well defined circular nucleus. DNA damage, as indicated by OTM, started to be evident as early as $12 \mathrm{~h}$ after treatment $(\mathrm{P}<0.05)$, and further increased in a time-dependent manner. After $48 \mathrm{~h}$, almost the entire population of HeLa cells contained damaged DNA.

\section{Discussion}

In this study, biologically active 3-(trifluoromethyl)phenyl piperazin moiety was introduced to the 2,2-dimethyl-2H-benzopyran template to form $\mathrm{C} 110 \mathrm{~g}$ and the cytotoxic effect on HeLa cells was evaluated. Our results showed that $\mathrm{C} 110 \mathrm{~g}$ significantly inhibited cell viability in a concentation- and time-dependent manner. With $\mathrm{IC}_{50}$ value of $17 \mu \mathrm{M}$ after 48 -h treatment, $\mathrm{C} 110 \mathrm{~g}$ enhanced the anticancer activity to a large extent, as compared to that of cromakalim analogues based on 2,2-dimethyl-2 $H$-benzopyran template in our previous study (21). According to their chemical structures, the increased activity may be due to the presence of trifluoromethylphenyl group in $\mathrm{C} 110 \mathrm{~g}$ which increases the lipophilicity and affects the partitioning of $\mathrm{C} 110 \mathrm{~g}$ into membranes and facilitates hydrophobic interactions of $\mathrm{C} 110 \mathrm{~g}$ with specific binding targets.

To gain better insights into the mechanism of cytotoxicity induced by $\mathrm{C} 110 \mathrm{~g}$, further investigation was done for the cellular and molecular mechanisms associated with the inhibitory role of $\mathrm{C} 110 \mathrm{~g}$ including apoptosis, cell cycle arrest and DNA damage. Marked morphological changes indicative of cell apoptosis were clearly observed and the apoptotic cell population increased time-dependently with $\mathrm{C} 110 \mathrm{~g}$ treatment. The Bcl-2 family proteins Bax (pro-apoptotic protein) and Bcl-2 (anti-apoptotic protein) play important roles in initiating the mitochondria-mediated apoptosis (30) and the ratio of Bax to $\mathrm{Bcl}-2$ is crucial to drug-induced disruption of $\Delta \Psi \mathrm{m}$ and the release of cytochrome $c$ into the cytosol (33). Although $\mathrm{C} 110 \mathrm{~g}$ had no significant effect on Bcl-2, the enhancement of Bax expression level significantly increased the ratio of Bax/ $\mathrm{Bcl}-2$, and then promoted the release of cytochrome $c$ from mitochondria (Fig. 5A). $\Delta \Psi \mathrm{m}$ was further determined by both rhodamine 123 and JC-1 staining assays. A significant reduction of $\Delta \Psi \mathrm{m}$ was observed using JC-1 staining, as indicated by a decrease in the red/green fluorescence intensity ratio (Fig. 4C). However, rhodamine 123 assay gave the opposite result with increasing fluorescent density (data not shown). This could be due to rhodamine 123 being a substrate of P-glycoprotein (P-gp), which is usually overexpressed in cancer cells and substances blocking calcium influx have been found to antagonize P-gp-mediated multidrug resistance (MDR) (34). Since a series of 4,6-disubstituted 2,2-dimethylbenzopyrans, structurally like $\mathrm{C} 110 \mathrm{~g}$, were reported to be potassium channel openers, leading to reduction of intracellular calcium (35-37), $\mathrm{C} 110 \mathrm{~g}$ might also block the calcium influx and inhibit P-gp activity. However, this need to be investigated in further detail later. Following the release of cytochrome $c$ into cytosol, it binds Apaf-1 and promotes caspase activation (7). While multiple caspases exist within the cell, initiator caspases are usually particular to specific pathways and as caspase- 9 is involved in the intrinsic pathway, caspase- 8 is typically associated with the initiation of the death-receptor pathways which are independent of mitochondria (38-41). In our study, the event is clear. After $24 \mathrm{~h}$ of $\mathrm{C} 110 \mathrm{~g}$ treatment, caspase-3, -8 and -9 were all activated in HeLa cells, indicating both intrinsic and extrinsic pathways are involved in the C110ginduced apoptosis.

The cell growth and inhibition are both tightly mediated through cell cycle control (42), and the dysregulation of cell cycle progression has been implicated in the initiation of apoptosis (43). C110g treatment resulted in a marked G1 phase cell cycle arrest accompanied by a decrease of $\mathrm{S}$-phase cells (Fig. 3A). Having a key role in cellular responses to various stimulations, p53 serves as a major barrier for carcinogenesis by inducing cell cycle arrest and apoptosis (44). P53-mediated cell cycle arrest is partly achieved through the transcriptional activation of $\mathrm{p} 21^{\mathrm{WAF} 1 / \mathrm{Cip} 1}$, a potent cyclin-dependent kinase inhibitors (CKI) from G1 to S-phase (45). Accumulation of p53 and induction of $\mathrm{p} 21$ by $\mathrm{C} 110 \mathrm{~g}$ were detected and peaked at the earliest time-points of 12-24 h, whereas increased levels of the apoptotic proteins Bax, cytosol cytochrome $c$, Apaf-1 and caspase family proteins peaked at $48 \mathrm{~h}$. Moreover, results from the comet assay showed obvious DNA-strand breaks after only $12 \mathrm{~h}$ of incubation with $\mathrm{C} 110 \mathrm{~g}$. Therefore, the G1 cell cycle arrest and apoptosis induced by $\mathrm{C} 110 \mathrm{~g}$ may, in part, be due to the induction of the DNA damage dependent p53-regulated signaling pathways.

In conclusion, based on these observations, we have obtained convincing evidence that $\mathrm{C} 110 \mathrm{~g}$ efficiently inhibits the growth of HeLa cell through p53- and mitochondriadependent pathways as shown in Fig. 7. Further investigation on both in vivo and in vitro cervical cancer models is needed. 


\section{Acknowledgements}

This study was supported by the 2011 Inje University research grant.

\section{References}

1. Jemal A, Bray F, Center MM, Ferlay J, Ward E and Forman D: Global cancer statistics. CA Cancer J Clin 61: 69-90, 2011.

2. Orren DK, Petersen LN and Bohr VA: Persistent DNA damage inhibits S-phase and G2 progression, and results in apoptosis. Mol Biol Cell 8: 1129-1142, 1997.

3. Fujimoto K, Hosotani R, Doi R, et al: Induction of cell-cycle arrest and apoptosis by a novel retinobenzoic-acid derivative, TAC-101, in human pancreatic cancer cells. Int J Cancer 81: 637-644, 1999.

4. Gamet-Payrastre L, Li P, Lumeau S, et al: Sulforaphane, a naturally occurring isothiocyanate, induces cell cycle arrest and apoptosis in HT29 human colon cancer cells. Cancer Res 60 : 1426-1433, 2000.

5. Gasser S: DNA damage response and development of targeted cancer treatments. Ann Med 39: 457-464, 2007.

6. Degterev A, Boyce M and Yuan J: A decade of caspases. Oncogene 22: 8543-8567, 2003.

7. Ghobrial IM, Witzig TE and Adjei AA: Targeting apoptosis pathways in cancer therapy. CA Cancer J Clin 55: 178-194, 2005.

8. Denault J-B and Salvesen GS: Caspases: keys in the ignition of cell death. Chem Rev 102: 4489-4500, 2002.

9. Cory S and Adams JM: The Bcl2 family: regulators of the cellular life-or-death switch. Nat Rev Cancer 2: 647-656, 2002.

10. Dia VP and Mejia EG: Lunasin promotes apoptosis in human colon cancer cells by mitochondrial pathway activation and induction of nuclear clusterin expression. Cancer Lett 295: 44-53, 2010.

11. Evans BE, Rittle KE, Bock MG, et al: Methods for drug discovery: development of potent, selective, orally effective cholecystokinin antagonists. J Med Chem 31: 2235-2246, 1988.

12. Nicolaou KC, Pfefferkorn JA, Roecker AJ, Cao GQ, Barluenga S and Mitchell HJ: Natural product-like combinatorial libraries based on privileged structures. 1. General principles and solidphase synthesis of benzopyrans. J Am Chem Soc 122: 9939-9953, 2000.

13. Clemence F, Le Martret O, Delevallee F, et al: 4-Hydroxy3 -quinolinecarboxamides with antiarthritic and analgesic activities. J Med Chem 31: 1453-1462, 1988.

14. Agbaje OC, Fadeyi OO, Fadeyi SA, Myles LE and Okoro CO: Synthesis and in vitro cytotoxicity evaluation of some fluorinated hexahydropyrimidine derivatives. Bioorg Med Chem Lett 21: 989-992, 2011.

15. Gui S-Y, Chen F-H, Zhou Q and Wang Y: Effects of novel all-trans retinoic acid retinamide derivatives on the proliferation and apoptosis of human lung adenocarcinoma cell line A549 cells. Yakugaku Zasshi 131: 1465-1472, 2011.

16. Tominaga $\mathrm{H}$, Ishiyama $\mathrm{M}$, Ohseto $\mathrm{F}$, et al: A water-soluble tetrazolium salt useful for colorimetric cell viability assay. Anal Commun 36: 47-50, 1999

17. Allen S, Sotos J, Sylte MJ and Czuprynski CJ: Use of Hoechst 33342 staining to detect apoptotic changes in bovine mononuclear phagocytes infected with Mycobacterium avium subsp. paratuberculosis. Clin Vaccine Immunol 8: 460-464, 2001.

18. Lin S-Y, Liu J-D, Chang H-C, Yeh S-D, Lin C-H and Lee W-S: Magnolol suppresses proliferation of cultured human colon and liver cancer cells by inhibiting DNA synthesis and activating apoptosis. J Cell Biochem 84: 532-544, 2002.

19. Jakubowski W and Bartosz G: 2,7-dichlorofluorescin oxidation and reactive oxygen species: what does it measure? Cell Biol Int 24: 757-760, 2000 .

20. Cossarizza A, Baccaranicontri M, Kalashnikova G and Franceschi C: A new method for the cytofluorimetric analysis of mitochondrial membrane potential using the J-aggregate forming lipophilic cation 5,5',6,6'-tetrachloro-1,1',3,3'-tetraethylbenzimidazolcarbocyanine iodide (JC-1). Biochem Biophys Res Commun 197: 40-45, 1993.
21. Zhang X, Zhao J, Kang S, et al: A novel cromakalim analogue induces cell cycle arrest and apoptosis in human cervical carcinoma HeLa cells through the caspase- and mitochondriadependent pathway. Int J Oncol 39: 1609-1617, 2011.

22. Miao C, Du J, Dang HT, Jeong IH, et al: Apoptotic activity of fatty acid derivatives may correlate with their inhibition of DNA replication. Int J Oncol 33: 1291-1298, 2008.

23. Hellman B, Vaghef $\mathrm{H}$ and Boström B: The concepts of tail moment and tail inertia in the single cell gel electrophoresis assay. DNA Repair 336: 123-131, 1995.

24. Rojas E, Lopez MC and Valverde M: Single cell gel electrophoresis assay: methodology and applications. J Chromatogr B Biomed Sci Appl 722: 225-254, 1999.

25. Ashby J, Tinwell H, Lefevre PA and Browne MA: The single cell gel electrophoresis assay for induced DNA damage (comet assay): measurement of tail length and moment. Mutagenesis 10: 85-90, 1995.

26. Strasser A, O'Connor L and Dixit VM: Apoptosis signaling. Annu Rev Biochem 69: 217-245, 2000.

27. Vermes I, Haanen C, Steffens-Nakken $H$ and Reutellingsperger C: A novel assay for apoptosis flow cytometric detection of phosphatidylserine expression on early apoptotic cells using fluorescein labelled Annexin V. J Immunol Methods 184: 39-51, 1995.

28. Del Bino G, Darzynkiewicz Z, Degraef C, Mosselmans R, Fokan D and Galand P: Comparison of methods based on Annexin-V binding, DNA content or TUNEL for evaluating cell death in HL-60 and adherent MCF-7 cells. Cell Prolif 32: 25-37, 1999.

29. Jo W-S, Jeong M-H, Jin Y-H, et al: Loss of mitochondrial membrane potential and caspase activation enhance apoptosis in irradiated K562 cells treated with herbimycin A. Int J Radiat Biol 81: 531-543, 2005.

30. Gross A, McDonnell JM and Korsmeyer SJ: BCL-2 family members and the mitochondria in apoptosis. Genes Dev 13: 1899-1911, 1999.

31. Norbury CJ and Zhivotovsky B: DNA damage-induced apoptosis. Oncogene 23: 2797-2808, 2004.

32. Hartmann A, Agurell E, Beevers C, et al: Recommendations for conducting the in vivo alkaline Comet assay. Mutagenesis 18: 45-51,2003.

33. Qi F, Inagaki Y, Gao B, et al: Bufalin and cinobufagin induce apoptosis of human hepatocellular carcinoma cells via Fas- and mitochondria-mediated pathways. Cancer Sci 102: 951-958, 2011.

34. Sulová Z, Seres M, Barancík M, Gibalová L, Uhrík B, Poleková $L$ and Breier A: Does any relationship exist between P-glycoprotein-mediated multidrug resistance and intracellular calcium homeostasis. Gen Physiol Biophys 28: 89-95, 2009.

35. Caliendo G, Grieco P, Perissutti E, et al: Synthesis, biological activity and conformational study of 1,4-benzoxazine derivatives as potassium channel modulators. Eur J Med Chem 33: 957-967, 1998.

36. Lee YS, Sayeed MM and Wurster D: In vitro antitumor activity of cromakalim in human brain tumor cells. Pharmacology 49: 69-74, 1994.

37. Sebille $\mathrm{S}$, de Tullio $\mathrm{P}$, Becker $\mathrm{B}$, et al: 4,6-Disubstituted 2,2-dimethylchromans structurally related to the K(ATP) channel opener cromakalim: design, synthesis, and effect on insulin release and vascular tone. J Med Chem 48: 614-621, 2004.

38. Chen $\mathrm{M}$ and Wang $\mathrm{J}$ : Initiator caspases in apoptosis signaling pathways. Apoptosis 7: 313-319, 2002.

39. Donepudi M and Grütter MG: Structure and zymogen activation of caspases. Biophys Chem 101-102: 145-153, 2002.

40. Hengartner MO: The biochemistry of apoptosis. Nature 407: $770-776,2000$

41. Yu J and Zhang L: The transcriptional targets of $\mathrm{p} 53$ in apoptosis control. Biochem Biophys Res Commun 331: 851-858, 2005.

42. Sánchez I and Dynlacht BD: New insights into cyclins, CDKs, and cell cycle control. Semin Cell Dev Biol 16: 311-321, 2005.

43. Lee S, Christakos S and Small MB: Apoptosis and signal transduction: clues to a molecular mechanism. Curr Opin Cell Biol 5: 286-291, 1993.

44. Martins CP, Brown-Swigart L and Evan GI: Modeling the therapeutic efficacy of p53 restoration in tumors. Cell 127: 1323-1334, 2006.

45. He G, Siddik ZH, Huang Z, et al: Induction of p21 by p53 following DNA damage inhibits both Cdk4 and Cdk2 activities. Oncogene 24: 2929-2943, 2005. 